\title{
Primer on tumor immunology and cancer immunotherapy
}

Timothy J Harris ${ }^{1}$ and Charles G Drake ${ }^{2^{*}}$

\begin{abstract}
Individualized cancer therapy is a central goal of cancer biologists. Immunotherapy is a rational means to this end-because the immune system can recognize a virtually limitless number of antigens secondary to the biology of genetic recombination in B and T lymphocytes. The immune system is exquisitely structured to distinguish self from non-self, as demonstrated by anti-microbial immune responses. Moreover the immune system has the potential to recognize self from "altered-self", which is the case for cancer. However, the immune system has mechanisms in place to inhibit self-reactive responses, many of which are usurped by evolving tumors. Understanding the interaction of cancer with the immune system provides insights into mechanisms that can be exploited to disinhibit anti-tumor immune responses. Here, we summarize the 2012 SITC Primer, reviewing past, present, and emerging immunotherapeutic approaches for the treatment of cancer-including targeting innate versus adaptive immune components; targeting and/or utilizing dendritic cells and T cells; the role of the tumor microenvironment; and immune checkpoint blockade.
\end{abstract}

Keywords: Immunotherapy, Cancer vaccine, Immune checkpoint, Adoptive T cell therapy

\section{Introduction}

The immune system is able to distinguish self from non-self, and is able to vigorously attack non-self and infected self tissues. This is the basis for anti-microbial responses. The immuno-editing theory suggests that the immune system is able to recognize and eradicate subclinical tumors, but at some point equilibrium is reached and the tumor remains in situ, in a state of balance with a partially efficacious response [1]. Unfortunately, many tumors escape from this equilibrium state, and cancer becomes clinically apparent. The goal of the cancer immunotherapist is to understand the mechanisms by which cancer is able to escape the immune system and to therapeutically intervene at critical points to promote anti-tumor immune responses. Broadly, such interventions fall under the umbrella of "immunotherapy" and can include cancer vaccines, cytokine therapy, the administration of monoclonal antibodies to block immune checkpoints, and others. The Society for Immunotherapy of Cancer (SITC)

\footnotetext{
* Correspondence: Cdrake@jhmi.edu

${ }^{2}$ Department of Oncology and Brady Urological Institute, Johns Hopkins University School of Medicine and Sidney Kimmel Comprehensive Cancer Center, 1650 Orleans St., CRB I \#410, Baltimore, MD 21231, USA

Full list of author information is available at the end of the article
}

organized a Primer on Tumor Immunology and Cancer Immunotherapy with the assistance of Willem W. Overwijk, $\mathrm{PhD}$ (Innate Immunity and Inflammation), Madhav Dhodapkar, MD (Dendritic Cells), Helen Chen, MD (Immunology of Antibodies as Therapy), Susan M. Kaech, PhD (Effector and Memory T Cell Differentiation), Thomas F. Gajewski, MD, PhD (Immunobiology of the Tumor Microenvironment), Jonathan Powell, MD, PhD (T Cell Intracellular Signaling), Pedro J. Romero, MD (Tumor Antigen and Immunogenicity), Charles G. Drake, $\mathrm{MD}, \mathrm{PhD}$ (Coinhibition and Costimulation), and Cassian Yee, MD (Adoptive Cellular Therapy). Mario Sznol, MD and Charles Drake, MD, PhD served as co-organizers.

\section{Review}

Innate immunity and inflammation

The innate immune system recognizes pathogens based on repeated patterns and responds quickly with a variety of effector mechanisms. This is in contrast to the adaptive immune system, consisting of $\mathrm{T}$ and $\mathrm{B}$ cells, which responds more slowly, but which is more specific. An innate immune response is often evidenced by Inflammation: a local response to tissue injury-defined by the presence of Rubor (redness), Calor (heat), Dolor (pain), and Tumor 
(swelling). The innate immune response functions to eradicate invasive pathogen; limit the spread of infection; initiate adaptive immune responses involving $\mathrm{T}$ and $\mathrm{B}$ cells; and to initiate tissue repair. Immune responses and inflammation are generally advantageous for the host, and may include suppressing growth of smaller tumors. Interestingly however, inflammation can also promote neoplastic transformation and tumor progression. For example, in a genetically engineered lung cancer model using mice with a mutation in K-ras, cigarette smoke induced inflammation and tumor development through the activation of myeloid cells [2]. In a preclinical model of squamous cell carcinoma related to HPV E6/E7, chronic inflammation caused by lymphocytes and Fc Gamma Receptor signaling on myeloid cells was responsible for malignant transformation, and tumorigenesis could be abrogated via lymphocyte depletion or Fc Gamma Receptor blockade [3]. Mutations within tumors can play a role in this process; BRAF mutations drive tumor cells to produce proinflammatory cytokines like VEGF, IL-10, and IL-6, while at the same time decreasing expression of anti-tumor cytokines such as IL-12 [4]. Mutated BRAF also promotes the secretion of IL- $1 \alpha$ and IL- $1 \beta$, innate inflammatory mediators which can drive tumor cells to protect themselves from immune attack by up-regulating molecules that inhibit the function of anti-tumor lymphocytes [5]. Another molecular mechanism linking chronic inflammation to cancer progression involves a transcription factor known as STAT3 (signal transducer and activator of transcription 3). In areas of chronic inflammation, tumors up-regulate activated (phosphorylated) STAT3, which, in addition to being anti-apoptotic, drives expression of cytokines that dysregulate anti-tumor immune responses [6]. Tumors can also cause systemic immunosuppression as noted in preclinical models demonstrating an increase in splenic myeloid suppressor cells, which are a specialized population of innate myeloid cells $[7,8]$. Taken together, these data provide examples of how the innate immune system can promote tumor progression, and suggest pathways for intervention.

\section{Dendritic cells}

Dendritic cells (DC) link the innate immune system to the adaptive immune response. These cells dwell in the tissues, continually sampling the microenvironment and taking up antigens primarily through pinocytosis. When the innate immune system is activated in their vicinity, DCs sense this as "danger" [9], cease antigen uptake and travel to local lymph nodes, where their role is to present antigen to specific $\mathrm{T}$ lymphocytes. The microenvironment in which a DC acquires antigen determines whether the DC will have the capacity to activate an antigen-specific lymphocyte or to tolerize the lymphocyte. In addition to pinocytosis, immature DCs are also able to internalize antigen through Fc receptor-mediated endocytosis, a process in which Fc receptors on the DC bind antibodybound antigen. Emerging data suggest that the subtype of Fc receptor involved in antigen internalization helps to determine whether the response to that antigen will be activating or inhibitory [10]. As introduced above, the ultimate outcome of the lymphocyte-DC interaction is based primarily on the state of the DC. DCs can produce distinct cytokine groups that can skew $\mathrm{T}$ lymphocytes toward divergent functions. Moreover, triggering distinct Toll-like receptors (TLRs) on DCs elicits different cytokine profiles and different immune responses. Signaling through TLRs 4, 5, or 11 results in DC production of IL-12, which in turn skews T-cells towards a $\mathrm{T}_{\mathrm{H}} 1$ phenotype capable of promoting anti-tumor immune responses [11]. Signaling through TLRs 1, 2, or 6 causes DCs to produce IL-10, which in turn promotes T-cell development towards regulatory or $\mathrm{T}_{\mathrm{H}} 2$ phenotypes incapable of promoting anti-tumor immune responses [11]. In mice, a subset of DCs that express CD8 is primarily responsible for priming anti-tumor immune responses [12]. Their human equivalent is thought to be $\mathrm{CD} 141^{+}$DCs [13-16]. These subsets are known to produce IL-12 and crosspresent antigens to lymphocytes.

How can our knowledge of DC biology be used to develop immunotherapy for patients? While it is clear that activation of these cells is desirable, there are two general approaches to achieve that end: ex vivo and in vivo activation. Ex vivo strategies for DC-based immunotherapies include generation of DCs from circulating monocytes via subsequent culture, as well as procedures in which DCs are derived from circulating $\mathrm{CD}_{3} 4^{+}$hematopoetic stem cells (HSCs). In the U.S., an immunotherapy based on ex vivo activated DCs has been FDA-approved to treat patients with metastatic prostate cancer. This product, sipuleucel-T is generated by incubating a patient's monocytes with a fusion protein that links the target antigen (Prostatic Acid Phosphatase) to the cytokine GM-CSF; here GM-CSF serves to mature the monocytes toward DCs, and assists in internalization of the antigen. After ex vivo incubation, the mixed cellular product, including maturing DCs, is re-infused into patients. In a randomized control trial for prostate cancer patients, this product resulted in a 4.1 month improvement in median survival compared to placebo (HR 0.78; $\mathrm{P}=0.03$ ) [17]. Another common strategy for DC-based immunotherapy involves maturation of immature monocytes into DCs by culturing them for several days in the presence of GM-CSF and IL4. The DCs are then loaded with tumor-specific peptides or in some variation with whole protein antigens which they must subsequently process and present [18]. While ex vivo stimulation of DCs often results in quantifiable immune and clinical responses with no dose limiting toxicities, the overall clinical response rates to this therapeutic 
approach have remained somewhat low [19]. The other major strategy under study is to target antigens specifically to DCs in vivo. This routinely involves the use an adjuvant (e.g. TLR agonist) in combination with signaling antibodies (e.g. anti-CD40, anti-DC-SIGN, anti-MMR, anti-DEC-205) and tumor-specific antigen [20]. In summary, an evolving understanding of DC biology has led to the first commercially approved cellular immunotherapy for the treatment (not prevention) of a solid tumor, and further developments in this field are likely.

\section{Antibodies as therapy}

Monoclonal antibodies are now widely utilized in the treatment of a number of tumor types; pertinent examples including trastuzumab (anti-Her-2) for the treatment of breast cancer, rituximab (anti-CD20) for the treatment of lymphoma, and the recently approved immunoconjugate T-DM1, which fuses trastuzumab to a highly potent chemotherapy, emtansine (DM1 [deacetyl maytansine]) to facilitate local delivery and minimize systemic toxicity [21]. Antibody-based immunotherapeutics can be exquisitely specific treatment tools, based on the diverse and nanomolar level affinity of the Fv region of the antibody for its target, as well as the ability of the Fc region to engage components of the host immune system. How do monoclonal antibodies work? The mechanisms of action of unconjugated monoclonal antibodies include blocking a pro-survival signal, as well as facilitating tumor cell destruction by the binding of the Fc portion of the antibody to Fc Receptors on natural killer (NK) cells-promoting the ability of NK cells to lyse their targets through a process known as antigen-dependent cytotoxicity (ADCC). Monoclonal antibodies can also mediate cytotoxicity by binding to complement receptors on effector cells, a process known as complement-dependent cytotoxicity (CDCC). The Fc portion of a monoclonal antibody plays a major role in determining the immune mechanisms induced, with monoclonal antibodies of the human IgG4 isotype primarily functioning as "blockers". One interesting aspect involved in the development of monoclonal antibodies for the clinic involves their affinity, while higher antibody affinity results in increased target engagement and ADCC, higher affinities can also result in decreased tumor penetration and compromised efficacy [22-24].

Several recent clinical developments highlight the increasingly prominent role of antibody-based therapy in cancer. In an important recent result, $\mathrm{Yu}$ et al. showed an $11 \%$ absolute benefit in 2-year survival in patients with advanced neuroblastoma treated with a combination of IL-2, GM-CSF, and an antibody targeting GD2 (disialoganglioside 2) $(\mathrm{P}=0.02)$ [25]. As discussed above, a great deal of recent interest involves conjugating monoclonal antibodies to either a cytotoxic agent, examples include brentuximab vedotin (anti-CD30-MMAE [monomethyl auristatin E]) for anaplastic large cell and Hodgkin lymphoma, trastuzumab emtansine (anti-HER2DM1) for breast cancer, and glembatumumab vedotin (anti-GPNMB-MMAE) for breast cancer [21,26,27]. In addition, $T$ cells can be re-engineered to express chimeric (antibody-based) antigen receptors (CARs) to target the powerful killing machinery of cytotoxic lymphocytes directly to tumor antigen [28]. CAR transformed $\mathrm{T}$ cells have been developed against a variety of antigens, including CEA, CAIX, EGFR, HER2, CD19, and CD20, but serious adverse events have been reported [29,30]. In a particularly relevant report, Porter et al. recently showed that a CAR specific for CD19 could mediate a major clinical response in a patient with chronic lymphocytic leukemia [29]. Another fascinating application of monoclonal antibody technology involves the engineering of bi-specific antibodies, in which one arm carries specificity for a tumor antigen, and the other arm is specific for the CD3 complex on $\mathrm{T}$ cells. The idea behind this technology is to physically co-localize lymphocytes to tumors, inducing anti-tumor $\mathrm{T}$ cell responses. Bi-specific antibodies against CD19 (blinatumomab) have shown promise in Phase I-II studies $[31,32]$.

\section{Tumor microenvironment}

In vivo, a tumor is significantly more complex than a simple group of clonogenic cells. The three-dimensional mass that is appreciated on imaging studies contains, in addition to tumor cells, extracelluar matrix components, supportive stromal cells (e.g. neovasculature, fibroblasts, and macrophages), and a number of inflammatory cells. In terms of mounting an anti-tumor immune response, there is further complexity involved, since the priming and effector phases of the immune response are separated by time and space. While priming occurs in lymph nodes, the effector functions must operate within the tumor mass. Potential barriers to anti-tumor responses encountered during the priming phase include a paucity of "danger" signals from innate immune cells, poor recruitment of DCs for cross-presentation, and inadequate expression of costimulatory ligands on tumor cells or APCs. Potential barriers to efficacy during the effector phase involve inadequate recruitment of activated effector $\mathrm{T}$ cells secondary to abnormal vascular endothelial cells and/or chemokines, the presence of dominant immune inhibitory mechanisms capable of abrogating $\mathrm{T}$ cell effector function (e.g. the inhibitory receptors PD-1 and CTLA-4), extrinsic suppressive cells ( $\mathrm{T}_{\mathrm{REGs}}$, myeloid-derived suppressor cells), metabolic inhibitors (IDO, arginase), and inhibitory cytokines (IL-10, TGF- $\beta$ ) [33].

The genetic profile of the tumor microenvironment and its potential correlation with anti-tumor immune responses has become an area of increased study in recent years. In one preclinical study of metastatic melanoma, 
the expression of a subset of chemokines were associated with $\mathrm{CD}^{+} \mathrm{T}$ cell infiltration [34]. In patients with metastatic melanoma, the expression of $\mathrm{T}$ cell markers and chemokines correlated with response to a DC-based vaccine [35]. Likewise, a pro-inflammatory gene expression profile within the tumor microenvironment was associated with survival following administration of a protein-based vaccine in patients with metastatic melanoma [36]. Response to CTLA-4 blockade in patients with metastatic melanoma was also correlated with expression of interferon inducible genes and $\mathrm{T}_{\mathrm{H}} 1$ associated markers [37]. Finally, expression of $\mathrm{T}$ cell homing genes in the tumor vascular endothelium has also been implicated in mitigating lymphocyte infiltration [38]. Two important implications of these data include the potential for improved patient selection for administration of immunotherapeutics and identifying potential strategies for improved response to immunotherapies in patient populations that would otherwise respond poorly to immunologic interventions.

\section{T cell intracellular signaling}

To understand how the adaptive arm of the immune system is engaged, a basic knowledge of $\mathrm{T}$ cell biology and activation can be helpful. $\mathrm{T}$ cells detect antigen bound to $\mathrm{MHC}$ molecules, with the $\mathrm{CD}^{+}{ }^{+} \mathrm{T}$ cell subset binding to MHC Class II primarily expressed on APCs while $\mathrm{CD}^{+} \mathrm{T}$ cells are activated by binding to $\mathrm{MHC}$ Class I, which can be expressed by APCs as well as normal cells. Following initial APC-driven activation, $\mathrm{CD}^{+}$ $\mathrm{T}$ cells may later recognize target cells expressing their cognate antigen, resulting in cell-mediated cytotoxicity. For $\mathrm{T}$ cells to be fully activated, the APC must provide other signals in addition to the peptide/MHC (signal 1). The B7-CD28 interaction, with B7 expressed on the APC and CD28 on T cells, was one of the first co-stimulatory signaling pathways elucidated [39]. CD28 signaling is complex, but most likely functions in part by increasing $\mathrm{T}$ cell expression of anti-apoptotic proteins (e.g. Bcl-xL) and autocrine growth factors like IL-2 [40,41]. Additional co-stimulatory interactions (APC:T-cell) include OX40LOX40, CD70-CD27, CD137L-CD137, and B7RP1-ICOS [42]. Ultimately, an effective tumor vaccine requires activating APCs to express appropriate co-stimulatory molecules to promote durable anti-tumor immune responses through intracellular signaling cascades.

Following $\mathrm{T}$ cell engagement with appropriately activated APCs, intracellular signaling results in activation of three signaling cascades: NF-AT, NF-kB, and AP-1 [43]. Of these, the NF-AT pathway is particularly interesting, since NF-AT signaling in the absence of AP-1 results in immune tolerance, whereas in vivo blockade of NF-AT decreases both $\mathrm{T}$ cell activation and limits tolerance $[44,45]$. Recent data showed that the Adenosine 2a Receptor
(A2aR) is a component of the negative feedback loop for $\mathrm{T}$ cell activation that is upregulated during $\mathrm{T}$ cell activation, and blockade of A2aR has been shown to increase the efficacy of tumor vaccines in pre-clinical models [46].

$\mathrm{T}$ cell activation is clearly influenced by the spectrum of cytokines present during antigen recognition, and several cytokines exert their immunologic effects by modulating the function of STAT proteins during $\mathrm{T}$ cell activation. In that regard, STAT4 has thus far been demonstrated to be crucial to $\mathrm{T}$ cell mediated anti-tumor immune responses. IL-12 activates STAT4, which in turn skews $\mathrm{T}$ cells toward a $\mathrm{T}_{\mathrm{H}} 1$ phenotype and IFN- $\gamma$ production [6]. Recent data show that, in addition to the canonical pathways such as NF-AT and AP-1, the mTOR (mammalian target of rapamycin) pathway also plays a critical role in $\mathrm{T}$ cell activation and function. $\mathrm{mTOR}$ is an evolutionarily conserved serine/threonine protein kinase central to integrating nutrient and hormone signaling pathways [47], which in turn regulates SGK1, a protein important in epithelial survival. In preclinical models, SGK1 knockout mice had increased response to tumor immunotherapy compared to mice with functional SGK1, suggesting that mTOR up-regulation dampens or inhibits anti-tumor immunity (unpublished data from Dr. Jonathan D. Powell, Johns Hopkins University). In summary, T cell activation is relatively complex, and is generally only partially understood, but plays a critical role in generating an adaptive anti-tumor immune response.

\section{Memory T-cells}

Following initial activation, a minority (5-10\%) of T cells become long-lived memory cells with enhanced functional responses upon antigen re-encounter as compared to naïve $\mathrm{T}$ cells. For cancer immunotherapy the importance of generating functional memory cells is two-fold. First, the presence of memory cells could potentially decrease metastatic spread and prevent tumor re-growth after an initial response. Second, memory cells could limit de novo induction of a second malignancy. The importance of tumor infiltrating memory $\mathrm{T}$ cells is further illustrated with the novel Immunoscore, which has demonstrated prognostic and predictive value in colorectal cancer through the quantification of tumor infiltrating cytotoxic effector cells and memory T cells [48]. Current understanding of memory $\mathrm{T}$ cells is derived largely from the study of the immune response to microbes; however, in the absence of good models of memory induction in tumor bearing animals or humans, one can reasonably extrapolate these findings to anti-tumor responses. It was originally hypothesized that memory $\mathrm{T}$ cells were selected randomly from the naïve $\mathrm{T}$ cell pool during the expansion phase of an effector response; but it is now thought that some $\mathrm{T}$ cells are intrinsically more likely than others to persist after an initial response as memory 
cells [49]. Thus, cells more likely to become memory cells express the IL-7 Receptor alpha (IL-7R $\alpha$ ) chain, CD27 (Tumor Necrosis Factor Receptor Superfamily 7), BCL-2, and downregulate the effector molecule KLRG1 (Killer Cell Lectin-like Receptor Subfamily G1) [50-52]. However, this expression profile is not exclusive to memory cells, as there are short-lived IL-7R $\alpha^{+}$cells that also have high expression of KLRG1 [50]. Memory cells can be divided into three relatively distinct subsets including: (1) "effector-memory" having more cytotoxic function; (2) "central-memory" cells, which likely represent the more classic quiescent memory cell with high proliferative capacity once re-stimulated; and (3) "tissueresident-memory" associated with an organ-specific distribution in vivo [53].

Multiple models exist for $\mathrm{T}$ cell diversification and longterm cell fate. The Separate-Precursor model, which is less feasible compared to other models that will be discussed, states that cells are pre-programmed in the thymus for subsequent development into a memory cell or an effector cell [53]. The Decreasing-Potential model postulates that repetitive exposure to antigen and stimuli drives $\mathrm{T}$ cells away from a memory phenotype towards terminal effector differentiation [53]. The Signal-Strength model proposes that memory cell development is dependent on the overall strength of the signals received by the $\mathrm{T}$ cell through antigen (signal 1), costimulation (signal 2), and pro-inflammatory cytokines (signal 3) [53]. Finally, the Asymmetric-Cell-Fate model posits that when a $\mathrm{T}$ cell encounters an APC and divides while still bound to the $\mathrm{APC}$, the daughter cell that remains attached to the DC (immunologic synapse) will receive greater signals through TCR and costimulation resulting in greater potential for terminal effector differentiation. Conversely, the daughter cell that is not adjacent to the immunologic synapse will have greater potential for memory cell differentiation [53].

Differential transcription factor expression is associated with the memory versus effector transcriptome. Tbet, BLIMP1, ID2, and STAT4 activity are associated with effector T cells [53,54]. Similarly, EOMES, BCL-6, and STAT3 activity are more associated with memory $\mathrm{T}$ cells $[53,55]$. Contemporary modeling supports a graded expression of these transcription factors resulting ultimately in the final lymphocyte phenotype. Additionally, there are metabolic differences between memory and effector $\mathrm{T}$ cells. Interestingly, memory cells-being more quiescent as compared to effector T cells-sustain ATP through fatty acid oxidation, whereas effector $\mathrm{T}$ cells utilize aerobic glycolysis and lipid synthesis [56]. In that regard, $\mathrm{mTOR}$ is at least partially responsible for the aerobic metabolism found in effector T cells [57].

When $\mathrm{T}$ cells are continually exposed to antigen, as is often the case for lymphocytes specific for tumor-associated antigens, there exists the potential for such $\mathrm{T}$ cells to become "exhausted". T cell exhaustion is characterized by loss of effector cytokine production (IL-2, TNF- $\alpha$, and IFN- $\gamma$ ), impaired proliferation, and decreased cytotoxicity. Whereas memory T cells require IL-7 and IL-15 for maintenance, exhausted $\mathrm{T}$ cells appear to be maintained via continued exposure to antigen. Exhausted T cells also have a distinct transcriptome with upregulation of BLIMP1, EOMES, BATF and down-regulation of T-bet. Furthermore, exhausted lymphocytes express negative regulatory surface molecules including PD-1, LAG-3, TIM-3, 2B4, and CD160 [58]. Exhaustion is clearly reversible in some cases, as PD-1 blockade in a viral model of exhaustion was able to rescue the $\mathrm{T}$ cells from their exhausted phenotype [59], and blocking these immune checkpoint molecules associated with exhaustion is showing promise in multiple clinical trials [60]. Taken together, these new insights into memory cell differentiation and function offer multiple novel avenues for intervention in terms of generating a productive anti-tumor response.

\section{Tumor antigens and immunogenicity}

$\mathrm{T}$ cells recognize antigen in the form of small peptides, derived from proteolysed substrates, and presented in the context of MHC molecules. MHC molecules are genetically diverse, and for each $\mathrm{MHC}$ variant, only specific peptide sequences from a given antigen are able to bind for presentation to $\mathrm{T}$ cells and subsequent induction of anti-tumor immune responses. Understanding the specific antigens recognized by the immune system and the specific peptide sequences presented on MHC can be important in improving immunotherapies directed against a specific antigen. Several approaches have been used to identify tumor specific antigens, including molecular cloning; sequencing of antigenic peptides; and computer algorithms, each of which has its relative benefits and deficiencies.

Multiple processing pathways exist for proteolysis of antigen through the proteosome and presentation in MHC molecules [61]. Determinants of a peptide's ability to induce an immune response (i.e. its "antigenicity") include its affinity to the MHC, as well as the affinity of the peptide/MHC complex for a given $\mathrm{T}$ Cell Receptor (TCR). A critical facet of this interaction is a set of amino acids which are integral to $\mathrm{MHC}$ binding, socalled MHC-anchor-residues. To induce more robust immune responses, it is possible to modify antigenic peptides in several ways. MHC variable peptides (MVP), for example, are peptides designed with amino acid point changes involving $\mathrm{MHC}$-contact residues, usually optimized for improved MHC affinity. Conversely, altered peptide ligands (APL) are peptides with amino acid substitutions designed to optimize interactions with the $\mathrm{T}$ cell receptor. These altered peptides have been used in an attempt to augment immune response against a 
specific antigen [62]. MVPs/APLs have been used in both the preclinical and clinical setting resulting in improved immunogenicity for a number of tumor antigens, including gp100, CEA, and NY-ESO/LAGE-1 [63-65]. Understanding the specific antigen/peptide associated with anti-tumor immune responses allows for monitoring of ongoing immunologic responses with ex vivo studies including enumeration via tetramer and functionality via IFN- $\gamma$ production, ELISPOT, lytic activity, functional avidity, and replicative history assayed via enumerating telomere length.

The term "cancer vaccine" encompasses a variety of approaches sharing the common goal of activating and expanding a population of specific $\mathrm{T}$ cells to generate an anti-tumor response. A variety of vaccine approaches have been explored, including synthetic peptides, recombinant virus-like particles (VLP), naked/stabilized nucleic acids, recombinant viruses, recombinant bacteria, and dendritic cells. One notable facet of cancer vaccines is that they must provide antigen (signal 1) in addition to a second signal (signal 2) to elicit full effector function. The addition of an appropriate adjuvant to a vaccine (i.e. a "danger" signal [9]), can be important in providing Signal 2. Despite a great deal of work, only two cancer vaccines have been approved for clinical use, including Oncophage (Russia, 2008) and Provenge (sipuleucel-T) (USA, 2010). The PSA-targeting viral vaccine ProstVac VF is currently in phase III trials worldwide $[17,66]$. Although monitoring vaccine responses in peripheral blood is challenging, recent studies suggest that patients treated with sipuleucel- $\mathrm{T}$ do mount detectable antigen-specific $T$ and $B$ cells responses, which correlate to some degree with outcome [67]. Clinically, single agent efficacy of most cancer vaccines is less obvious, with objective clinical responses rarely detected [68]. Although multiple mechanisms may underlie this observation, data showing expression of immune checkpoint molecules like PD-1 and CTLA-4 on tumor-specific lymphocytes suggests that combining immune checkpoint blockade with vaccination might be one way to optimize a vaccine-initiated anti-tumor immune response [69].

\section{Coinhibition and costimulation in cancer immunotherapy}

As discussed above, the T-cell/APC interaction involves engagement of the TCR with the antigen-MHC complex; in addition, costimulation/coinhibition interactions also occur and these secondary receptor/ligand binding events ultimately affect downstream $\mathrm{T}$ cell responses. Classically, costimulation involves the interaction of B7CD28-disruption of this interaction by CTLA-4 expression on $\mathrm{T}$ cells, with associated tight binding to B7 is referred to as co-inhibition [39,70]. Early preclinical studies demonstrated that blockade of CTLA-4 could mitigate inhibition of anti-tumor immune responses [71]. This finding was eventually confirmed clinically in Phase III trials in patients with metastatic melanoma [72]. In addition to CTLA-4, tumor infiltrating lymphocytes may express the negative regulatory receptors PD-1, LAG-3, TIM-3 and others [73-75]. Preclinical blockade of these pathways results in improved anti-tumor immunity [76-78]. Interestingly, a single tumor-infiltrating lymphocyte may express multiple immune checkpoint molecules simultaneously, so it is not surprising that combined blockade suggests improved efficacy in preclinical models [77]. The ligand for PD-1 is PD-L1, and expression of PD-L1 in tumors correlated with patient response to anti-PD-1 therapy [79]. These data would suggest that there could be potential biomarkers for checkpoint blockade therapy. Current preclinical studies are combining checkpoint blockade with tyrosine kinase inhibitors, radiation therapy and cancer vaccines.

\section{Adoptive cellular therapy}

Adoptive $\mathrm{T}$ cell therapy allows for ex vivo stimulation of lymphocytes in a non-tolerizing environment followed by re-infusion of activated $\mathrm{T}$ cells into patients. There are varying sources and types of $\mathrm{T}$ cells used for adoptive therapy, these include tumor infiltrating lymphocytes (TILs), $\mathrm{T}$ cells engineered to express a cancer-specific TCR, and T cells engineered to express a chimeric antigen receptor (CAR) that combines the extracellular portion of an antibody with the $\mathrm{T}$ cell receptor signaling machinery. Of these approaches, expanded TILs are the least labor intensive to produce, yet require an invasive procedure to obtain. Additionally, maintenance of TILs after adoptive transfer usually requires high dose IL-2, which results in significant toxicity. Clinical response rates in patients with metastatic melanoma treated with expanded TILs is impressive, approximately 50\% in several studies [80]. Furthermore, pretreatment of patients with lymphodepletion can result in a greater proportion of clinical responses and more durable responses [81]. As previously discussed, host $\mathrm{T}$ cells can be re-engineered to express CAR in place of the TCR. The CAR expresses an antibody Fv region in place of the extracellular domain of the TCR allowing the $\mathrm{T}$ cell to recognize whole antigen as opposed to MHC-restricted antigen [82]. This approach is efficient and results in $\mathrm{T}$ cells with uniform specificity, but is limited to some degree by transduction efficiency and potential toxicity. Another approach to adoptive $\mathrm{T}$ cell therapy is the use of endogenous tumor-specific $\mathrm{T}$ cells. This approach involves pheresis of circulating tumor-specific $\mathrm{T}$ cells, in vitro expansion and activation, and lastly reintroduction into the host via adoptive transfer [83]. This approach is considered to be the most physiologic, but is most labor intensive as it involves multiple pheresis sessions and 
significant laboratory labor for the expansion and activa-tion steps. Given the recent high-profile success of chimeric antigen receptor modified $\mathrm{T}$ cells for patients with CLL, these approaches are attracting increasing attention and enthusiasm $[29,84]$.

\section{Conclusions}

The immune system is exquisitely poised to recognize and distinguish self from non-self. Further, the immune system is able to recognize self from "altered-self", which is the case for cancer. Although clinically apparent malignancies have likely circumvented endogenous anti-tumor immune responses, immunotherapy has the potential to augment responses in order to mitigate tumor progression. As reviewed above, immune responses can be divided between innate and adaptive responses. Innate immune responses recognize general patterns of non-self (e.g. double-stranded RNA, single-stranded DNA, LPS) and are able to initiate pro-inflammatory responses which in turn can attract immune components leading to adaptive immunity. Adaptive immunity is defined by acquired immunity to specific antigens, and is mediated through $B$ cells via antibody secretion and $\mathrm{T}$ cells through cellmediated immunity. Dendritic cells are antigen presenting cells which function at the crossroads of innate and adaptive immunity and are able to cross-present antigen to, and activate, $\mathrm{T}$ cells. Dendritic cells are a target of various immunotherapeutic approaches either through the use of adjuvant cytokines which activate dendritic cells or more directly through the use of dendritic cell vaccines. Antibodies produced by B cells are highly specific for cognate antigen and have been engineered through various mechanisms to simultaneously target the tumor antigen and potentiate anti-tumor immune responses. $\mathrm{T}$ cells are ultimately responsible for cell-mediated immune responses, which are thought to be the most important mechanism of immune related tumor killing for solid malignancies. T cells can be activated through antibody blockade of inhibitory signaling, vaccination, or ex vivo stimulation followed by adoptive transfer into patients. A more complete understanding of the cellular and molecular components of the tumor-immune system interaction is crucial to the development of rational and efficacious immunotherapies in the future. This primer serves as a starting point for the cancer biologist and budding immunotherapist to better understand and appreciate the past, present, and future of immunotherapeutics.

\section{Competing interests}

The authors declare that they have no competing interests.

\section{Authors' contributions}

TH and CG contributed equally to the background research and writing of this review. Both authors read and approved the final manuscript.

\section{Author details}

'Department of Radiation Oncology \& Molecular Radiation Sciences, Johns Hopkins University School of Medicine and Sidney Kimmel Comprehensive Cancer Center, Baltimore, MD, USA. ${ }^{2}$ Department of Oncology and Brady Urological Institute, Johns Hopkins University School of Medicine and Sidney Kimmel Comprehensive Cancer Center, 1650 Orleans St., CRB I \#410, Baltimore, MD 21231, USA.

Received: 4 April 2013 Accepted: 10 July 2013

Published: 29 July 2013

\section{References}

1. Dunn GP, Bruce AT, Ikeda H, Old LJ, Schreiber RD: Cancer immunoediting: from immunosurveillance to tumor escape. Nat Immunol 2002, 3:991-998.

2. Takahashi H, Ogata H, Nishigaki R, Broide DH, Karin M: Tobacco smoke promotes lung tumorigenesis by triggering IKKbeta- and JNK1-dependent inflammation. Canc Cell 2010, 17:89-97.

3. Andreu P, Johansson M, Affara NI, Pucci F, Tan T, Junankar S, Korets L, Lam J, Tawfik D, DeNardo DG, Naldini L, de Visser KE, De Palma M, Coussens LM: FcRgamma activation regulates inflammation-associated squamous carcinogenesis. Canc Cell 2010, 17:121-134.

4. Sumimoto H, Imabayashi F, Iwata T, Kawakami Y: The BRAF-MAPK signaling pathway is essential for cancer-immune evasion in human melanoma cells. J Exp Med 2006, 203:1651-1656.

5. Khalili JS, Liu S, Rodriguez-Cruz TG, Whittington M, Wardell S, Liu C, Zhang M, Cooper ZA, Frederick DT, Li Y J Joseph RW, Bernatchez C, Ekmekcioglu S, Grimm E, Radvanyi LG, Davis RE, Davies MA, Wargo JA, Hwu P, Lizee G: Oncogenic BRAF(V600E) promotes stromal cell-mediated immunosuppression via induction of interleukin-1 in melanoma. Clin Canc Res 2012, 18:5329-5340.

6. Yu H, Pardoll D, Jove R: STATs in cancer inflammation and immunity: a leading role for STAT3. Nat Rev Canc 2009, 9:798-809.

7. Bronte V, Chappell DB, Apolloni E, Cabrelle A, Wang M, Hwu P, Restifo NP: Unopposed production of granulocyte-macrophage colony-stimulating factor by tumors inhibits CD8+ T cell responses by dysregulating antigen-presenting cell maturation. J Immunol 1999, 162:5728-5737.

8. Ugel S, Delpozzo F, Desantis G, Papalini F, Simonato F, Sonda N, Zilio S, Bronte V: Therapeutic targeting of myeloid-derived suppressor cells. Curr Opin Pharmacol 2009, 9:470-481.

9. Fuchs EJ, Matzinger P: Is cancer dangerous to the immune system? Semin Immunol 1996, 8:271-280.

10. Nimmerjahn F, Ravetch JV: Fcgamma receptors as regulators of immune responses. Nat Rev Immunol 2008, 8:34-47.

11. Pulendran B, Ahmed R: Translating innate immunity into immunological memory: implications for vaccine development. Cell 2006, 124:849-863.

12. Hashimoto D, Miller J, Merad M: Dendritic cell and macrophage heterogeneity in vivo. Immunity 2011, 35:323-335.

13. Bachem A, Guttler S, Hartung E, Ebstein F, Schaefer M, Tannert A, Salama A Movassaghi K, Opitz C, Mages HW, Henn V, Kloetzel PM, Gurka S, Kroczek RA: Superior antigen cross-presentation and XCR1 expression define human CD11C + CD141+ cells as homologues of mouse CD8+ dendritic cells. J Exp Med 2010, 207:1273-1281.

14. Crozat K, Guiton R, Contreras V, Feuillet V, Dutertre CA, Ventre E, Vu Manh TP, Baranek T, Storset AK, Marvel J, Boudinot P, Hosmalin A, Schwartz-Cornil I, Dalod M: The XC chemokine receptor 1 is a conserved selective marker of mammalian cells homologous to mouse CD8alpha + dendritic cells. J Exp Med 2010, 207:1283-1292.

15. Jongbloed SL, Kassianos AJ, McDonald KJ, Clark GJ, Ju X, Angel CE, Chen CJ, Dunbar PR, Wadley RB, Jeet V, Vulink AJ, Hart DN, Radford KJ: Human CD141+ (BDCA-3) + dendritic cells (DCs) represent a unique myeloid DC subset that cross-presents necrotic cell antigens. J Exp Med 2010, 207:1247-1260.

16. Poulin LF, Salio M, Griessinger E, Anjos-Afonso F, Craciun L, Chen JL, Keller AM, Joffre O, Zelenay S, Nye E, Le Moine A, Faure F, Donckier V, Sancho D, Cerundolo V, Bonnet D, Reis e Sousa C: Characterization of human DNGR-1+ BDCA3 + leukocytes as putative equivalents of mouse CD8alpha + dendritic cells. J Exp Med 2010, 207:1261-1271.

17. Kantoff PW, Higano CS, Shore ND, Berger ER, Small EJ, Penson DF, Redfern CH, Ferrari AC, Dreicer R, Sims RB, Xu Y, Frohlich MW, Schellhammer PF: Sipuleucel-T immunotherapy for castration-resistant prostate cancer. N Engl J Med 2010, 363:411-422. 
18. Dhodapkar MV, Steinman RM, Sapp M, Desai H, Fossella C, Krasovsky J, Donahoe SM, Dunbar PR, Cerundolo V, Nixon DF, Bhardwaj N: Rapid generation of broad T-cell immunity in humans after a single injection of mature dendritic cells. J Clin Invest 1999, 104:173-180.

19. Rosenberg SA, Yang JC, Restifo NP: Cancer immunotherapy: moving beyond current vaccines. Nat Med 2004, 10:909-915.

20. Palucka K, Banchereau J, Mellman I: Designing vaccines based on biology of human dendritic cell subsets. Immunity 2010, 33:464-478.

21. Verma S, Miles D, Gianni L, Krop IE, Welslau M, Baselga J, Pegram M, Oh DY, Dieras V, Guardino E, Fang L, Lu MW, Olsen S, Blackwell K: Trastuzumab emtansine for HER2-positive advanced breast cancer. N Engl J Med 2012, 367:1783-1791.

22. Fujimori $\mathrm{K}$, Covell DG, Fletcher JE, Weinstein JN: A modeling analysis of monoclonal antibody percolation through tumors: a binding-site barrier. J Nucl Med 1990, 31:1191-1198.

23. Adams GP, Schier R, McCall AM, Simmons HH, Horak EM, Alpaugh RK, Marks JD, Weiner LM: High affinity restricts the localization and tumor penetration of single-chain fv antibody molecules. Canc Res 2001, 61:4750-4755.

24. Rudnick SI, Lou J, Shaller CC, Tang Y, Klein-Szanto AJ, Weiner LM, Marks JD, Adams GP: Influence of affinity and antigen internalization on the uptake and penetration of Anti-HER2 antibodies in solid tumors. Canc Res 2011, 71:2250-2259.

25. Yu AL, Gilman AL, Ozkaynak MF, London WB, Kreissman SG, Chen HX, Smith M, Anderson B, Villablanca JG, Matthay KK, Shimada H, Grupp SA, Seeger R, Reynolds CP, Buxton A, Reisfeld RA, Gillies SD, Cohn SL, Maris JM, Sondel PM: Anti-GD2 antibody with GM-CSF, interleukin-2, and isotretinoin for neuroblastoma. N Engl J Med 2010, 363:1324-1334.

26. Pro B, Advani R, Brice P, Bartlett NL, Rosenblatt JD, Illidge T, Matous J, Ramchandren R, Fanale M, Connors JM, Yang Y, Sievers EL, Kennedy DA, Shustov A: Brentuximab vedotin (SGN-35) in patients with relapsed or refractory systemic anaplastic large-cell lymphoma: results of a phase II study. J Clin Oncol 2012, 30:2190-2196.

27. Rose AA, Grosset AA, Dong Z, Russo C, Macdonald PA, Bertos NR, St-Pierre Y, Simantov R, Hallett M, Park M, Gaboury L, Siegel PM: Glycoprotein nonmetastatic $B$ is an independent prognostic indicator of recurrence and a novel therapeutic target in breast cancer. Clin Canc Res 2010, 16:2147-2156.

28. Sadelain M, Brentjens $R$, Riviere I: The promise and potential pitfalls of chimeric antigen receptors. Curr Opin Immunol 2009, 21:215-223.

29. Porter $\mathrm{DL}$, Levine $\mathrm{BL}$, Kalos $\mathrm{M}$, Bagg $\mathrm{A}$, June $\mathrm{CH}$ : Chimeric antigen receptor-modified T cells in chronic lymphoid leukemia. N Engl J Med 2011, 365:725-733

30. Morgan RA, Yang JC, Kitano M, Dudley ME, Laurencot CM, Rosenberg SA Case report of a serious adverse event following the administration of $T$ cells transduced with a chimeric antigen receptor recognizing ERBB2. Mol Ther 2010, 18:843-851.

31. Bargou R, Leo E, Zugmaier G, Klinger M, Goebeler M, Knop S, Noppeney R, Viardot A, Hess G, Schuler M, Einsele H, Brandl C, Wolf A, Kirchinger P, Klappers P, Schmidt M, Riethmuller G, Reinhardt C, Baeuerle PA, Kufer P: Tumor regression in cancer patients by very low doses of a $T$ cell-engaging antibody. Science 2008, 321:974-977.

32. Topp MS, Gokbuget N, Zugmaier G, Degenhard E, Goebeler ME, Klinger M, Neumann SA, Horst HA, Raff T, Viardot A, Stelljes M, Schaich M, Kohne-Volland R, Bruggemann M, Ottmann OG, Burmeister T, Baeuerle PA, Nagorsen D, Schmidt M, Einsele H, Riethmuller G, Kneba M, Hoelzer D, Kufer $P$, Bargou RC: Long-term follow-up of hematologic relapse-free survival in a phase 2 study of blinatumomab in patients with MRD in B-lineage ALL. Blood 2012, 120:5185-5187.

33. Gajewski TF, Fuertes M, Spaapen R, Zheng Y, Kline J: Molecular profiling to identify relevant immune resistance mechanisms in the tumor microenvironment. Curr Opin Immunol 2011, 23:286-292.

34. Harlin $H$, Meng $Y$, Peterson AC, Zha $Y$, Tretiakova M, Slingluff $C$, McKee M, Gajewski TF: Chemokine expression in melanoma metastases associated with CD8+ T-cell recruitment. Canc Res 2009, 69:3077-3085.

35. Gajewski T, Zha Y, Thurner B, Schuler G: Association of gene expression profile in metastatic melanoma and survival to a dendritic cell-based vaccine. J Clin Oncol 2009, 27:9002.

36. Ulloa-Montoya F, Louahed J, Dizier B, Gruselle O, Spiessens B, Lehmann FF, Suciu S, Kruit WH, Eggermont AM, Vansteenkiste J, Brichard VG: Predictive Gene Signature in MAGE-A3 Antigen-Specific Cancer Immunotherapy. J Clin Oncol 2013, 31:2388-2395.
37. Ji RR, Chasalow SD, Wang L, Hamid O, Schmidt H, Cogswell J, Alaparthy S, Berman D, Jure-Kunkel M, Siemers NO, Jackson JR, Shahabi V: An immune-active tumor microenvironment favors clinical response to ipilimumab. Canc Immunol Immunother 2012, 61:1019-1031.

38. Buckanovich RJ, Facciabene A, Kim S, Benencia F, Sasaroli D, Balint K, Katsaros D, O'Brien-Jenkins A, Gimotty PA, Coukos G: Endothelin B receptor mediates the endothelial barrier to $T$ cell homing to tumors and disables immune therapy. Nat Med 2008, 14:28-36.

39. Azuma M, Cayabyab M, Buck D, Phillips JH, Lanier LL: CD28 interaction with B7 costimulates primary allogeneic proliferative responses and cytotoxicity mediated by small, resting T lymphocytes. J Exp Med 1992, 175:353-360.

40. Yang SY, Denning SM, Mizuno S, Dupont B, Haynes BF: A novel activation pathway for mature thymocytes. Costimulation of $C D 2$ $(T, p 50)$ and CD28 ( $T, p 44)$ induces autocrine interleukin 2/interleukin 2 receptor-mediated cell proliferation. J Exp Med 1988, 168:1457-1468.

41. Boise LH, Minn AJ, Noel PJ, June CH, Accavitti MA, Lindsten T, Thompson CB: CD28 costimulation can promote T cell survival by enhancing the expression of BCl-XL. Immunity 1995, 3:87-98.

42. Driessens G, Kline J, Gajewski TF: Costimulatory and coinhibitory receptors in anti-tumor immunity. Immunol Rev 2009, 229:126-144.

43. Sieber M, Baumgrass R: Novel inhibitors of the calcineurin/NFATc hub - alternatives to CsA and FK506? Cell Commun Signal 2009, 7:25.

44. Macian F, Garcia-Cozar F, Im SH, Horton HF, Byrne MC, Rao A: Transcriptional mechanisms underlying lymphocyte tolerance. Cell 2002, 109:719-731.

45. lannone R, Casella JF, Fuchs EJ, Chen AR, Jones RJ, Woolfrey A, Amylon M, Sullivan KM, Storb RF, Walters MC: Results of minimally toxic nonmyeloablative transplantation in patients with sickle cell anemia and beta-thalassemia. Biol Blood Marrow Transplant 2003, 9:519-528.

46. Ohta A, Gorelik E, Prasad SJ, Ronchese F, Lukashev D, Wong MK, Huang X, Caldwell S, Liu K, Smith P, Chen JF, Jackson EK, Apasov S, Abrams S, Sitkovsky M: A2A adenosine receptor protects tumors from antitumor $T$ cells. Proc Natl Acad Sci USA 2006, 103:13132-13137.

47. Powell JD, Pollizzi KN, Heikamp EB, Horton MR: Regulation of immune responses by mTOR. Annu Rev Immunol 2012, 30:39-68.

48. Angell H, Galon J: From the immune contexture to the Immunoscore: the role of prognostic and predictive immune markers in cancer. Curr Opin Immunol 2013, 25:261-267.

49. Antia R, Ganusov W, Ahmed R: The role of models in understanding CD8+ T-cell memory. Nat Rev Immunol 2005, 5:101-111.

50. Sarkar S, Kalia V, Haining WN, Konieczny BT, Subramaniam S, Ahmed R: Functional and genomic profiling of effector CD8 T cell subsets with distinct memory fates. J Exp Med 2008, 205:625-640.

51. Hendriks J, Gravestein LA, Tesselaar K, van Lier RA, Schumacher TN, Borst J: CD27 is required for generation and long-term maintenance of $T$ cell immunity. Nat Immunol 2000, 1:433-440.

52. Grayson JM, Zajac AJ, Altman JD, Ahmed R: Cutting edge: increased expression of $\mathrm{Bcl}-2$ in antigen-specific memory CD8+ T cells. J Immunol 2000, 164:3950-3954.

53. Kaech SM, Cui W: Transcriptional control of effector and memory CD8+ T cell differentiation. Nat Rev Immunol 2012, 12:749-761.

54. Joshi NS, Cui W, Chandele A, Lee HK, Urso DR, Hagman J, Gapin L, Kaech SM: Inflammation directs memory precursor and short-lived effector CD8(+) T cell fates via the graded expression of T-bet transcription factor. Immunity 2007, 27:281-295.

55. Banerjee A, Gordon SM, Intlekofer AM, Paley MA, Mooney EC, Lindsten T, Wherry EJ, Reiner SL: Cutting edge: The transcription factor eomesodermin enables CD8+ T cells to compete for the memory cell niche. J Immunol 2010, 185:4988-4992.

56. Pearce EL: Metabolism in T cell activation and differentiation. Curr Opin Immunol 2010, 22:314-320.

57. Chi $\mathrm{H}$ : Regulation and function of mTOR signalling in $\mathrm{T}$ cell fate decisions. Nat Rev Immunol 2012, 12:325-338.

58. Wherry EJ: T cell exhaustion. Nat Immunol 2011, 12:492-499.

59. Barber DL, Wherry EJ, Masopust D, Zhu B, Allison JP, Sharpe AH, Freeman GJ, Ahmed R: Restoring function in exhausted CD8 T cells during chronic viral infection. Nature 2006, 439:682-687.

60. Pardoll DM: The blockade of immune checkpoints in cancer immunotherapy. Nat Rev Canc 2012, 12:252-264.

61. Vigneron $\mathrm{N}$, van den Eynde BJ: Insights into the processing of MHC class I ligands gained from the study of human tumor epitopes. Cell Mol Life Sci 2011, 68:1503-1520. 
62. Edwards $L$, Evavold BD: T cell recognition of weak ligands: roles of signaling, receptor number, and affinity. Immunol Res 2011, 50:39-48.

63. Salgaller ML, Marincola FM, Cormier JN, Rosenberg SA: Immunization against epitopes in the human melanoma antigen gp100 following patient immunization with synthetic peptides. Canc Res 1996, 56:4749-4757.

64. Iero M, Squarcina P, Romero P, Guillaume P, Scarselli E, Cerino R, Carrabba $M$, Toutirais O, Parmiani G, Rivoltini L: Low TCR avidity and lack of tumor cell recognition in $\mathrm{CD} 8(+) \mathrm{T}$ cells primed with the CEA-analogue CAP1-6D peptide. Canc Immunol Immunother 2007, 56:1979-1991.

65. Valmori D, Dutoit V, Lienard D, Rimoldi D, Pittet MJ, Champagne P, Ellefsen K, Sahin U, Speiser D, Lejeune F, Cerottini JC, Romero P: Naturally occurring human lymphocyte antigen-A2 restricted CD8+ T-cell response to the cancer testis antigen NY-ESO-1 in melanoma patients. Canc Res 2000, 60:4499-4506.

66. Kim JW, Gulley JL: Poxviral vectors for cancer immunotherapy. Expert Opin Biol Ther 2012, 12:463-478.

67. Sheikh NA, Petrylak D, Kantoff PW, Dela Rosa C, Stewart FP, Kuan LY, Whitmore JB, Trager JB, Poehlein CH, Frohlich MW, Urdal DL: Sipuleucel-T immune parameters correlate with survival: an analysis of the randomized phase 3 clinical trials in men with castration-resistant prostate cancer. Canc Immunol Immunother 2013, 62:137-147.

68. Wood C, Srivastava P, Bukowski R, Lacombe L, Gorelov Al, Gorelov S, Mulders P, Zielinski H, Hoos A, Teofilovici F, Isakov L, Flanigan R, Figlin R, Gupta R, Escudier B: An adjuvant autologous therapeutic vaccine (HSPPC-96; vitespen) versus observation alone for patients at high risk of recurrence after nephrectomy for renal cell carcinoma: a multicentre, open-label, randomised phase III trial. Lancet 2008, 372:145-154.

69. Sierro SR, Donda A, Perret R, Guillaume P, Yagita H, Levy F, Romero P: Combination of lentivector immunization and low-dose chemotherapy or PD-1/PD-L1 blocking primes self-reactive T cells and induces anti-tumor immunity. Eur J Immunol 2011, 41:2217-2228.

70. Tivol EA, Borriello F, Schweitzer AN, Lynch WP, Bluestone JA, Sharpe AH: Loss of CTLA-4 leads to massive lymphoproliferation and fatal multiorgan tissue destruction, revealing a critical negative regulatory role of CTLA-4. Immunity 1995, 3:541-547.

71. Chambers CA, Kuhns MS, Egen JG, Allison JP: CTLA-4-mediated inhibition in regulation of $\mathrm{T}$ cell responses: mechanisms and manipulation in tumor immunotherapy. Annu Rev Immunol 2001, 19:565-594.

72. Hodi FS, O'Day SJ, McDermott DF, Weber RW, Sosman JA, Haanen JB, Gonzalez R, Robert C, Schadendorf D, Hassel JC, Akerley W, van den Eertwegh AJ, Lutzky J, Lorigan P, Vaubel JM, Linette GP, Hogg D, Ottensmeier CH, Lebbe C, Peschel C, Quirt I, Clark JI, Wolchok JD, Weber JS, Tian J, Yellin MJ, Nichol GM, Hoos A, Urba WJ: Improved survival with ipilimumab in patients with metastatic melanoma. N Engl I Med 2010, 363:711-723.

73. Sfanos KS, Bruno TC, Meeker AK, De Marzo AM, Isaacs WB, Drake CG: Human prostate-infiltrating CD8+ T lymphocytes are oligoclonal and PD-1+. Prostate 2009, 69:1694-1703.

74. Matsuzaki J, Gnjatic S, Mhawech-Fauceglia P, Beck A, Miller A, Tsuji T, Eppolito C, Qian F, Lele S, Shrikant P, Old L, Odunsi K: Tumor-infiltrating NY-ESO-1specific CD8+ T cells are negatively regulated by LAG-3 and PD-1 in human ovarian cancer. Proc Natl Acad Sci USA 2010, 107:7875-7880.

75. Fourcade J, Sun Z, Benallaoua M, Guillaume P, Luescher IF, Sander C, Kirkwood JM, Kuchroo V, Zarour HM: Upregulation of Tim-3 and PD-1 expression is associated with tumor antigen-specific CD8+ T cell dysfunction in melanoma patients. J Exp Med 2010, 207:2175-2186.

76. Iwai Y, Ishida M, Tanaka Y, Okazaki T, Honjo T, Minato N: Involvement of PD-L1 on tumor cells in the escape from host immune system and tumor immunotherapy by PD-L1 blockade. Proc Natl Acad Sci USA 2002, 99:12293-12297.

77. Woo SR, Turnis ME, Goldberg MV, Bankoti J, Selby M, Nirschl CJ, Bettini ML, Gravano DM, Vogel P, Liu CL, Tangsombatvisit S, Grosso JF, Netto G, Smeltzer MP, Chaux A, Utz PJ, Workman CJ, Pardoll DM, Korman AJ, Drake CG, Vignali DA: Immune inhibitory molecules LAG-3 and PD-1 synergistically regulate T-cell function to promote tumoral immune escape. Canc Res 2012, 72:917-927.

78. Ngiow SF, von Scheidt B, Akiba H, Yagita H, Teng MW, Smyth MJ: Anti-TIM3 antibody promotes T cell IFN-gamma-mediated antitumor immunity and suppresses established tumors. Canc Res 2011, 71:3540-3551.

79. Topalian SL, Hodi FS, Brahmer JR, Gettinger SN, Smith DC, McDermott DF, Powderly JD, Carvajal RD, Sosman JA, Atkins MB, Leming PD, Spigel DR, Antonia SJ, Horn L, Drake CG, Pardoll DM, Chen L, Sharfman WH, Anders RA,
Taube JM, McMiller TL, Xu H, Korman AJ, Jure-Kunkel M, Agrawal S, McDonald D, Kollia GD, Gupta A, Wigginton JM, Sznol M: Safety, activity, and immune correlates of anti-PD-1 antibody in cancer. N Engl J Med 2012, 366:2443-2454.

80. Dudley ME, Wunderlich JR, Robbins PF, Yang JC, Hwu P, Schwartzentruber DJ, Topalian SL, Sherry R, Restifo NP, Hubicki AM, Robinson MR, Raffeld M, Duray P, Seipp CA, Rogers-Freezer L, Morton KE, Mavroukakis SA, White DE, Rosenberg SA: Cancer regression and autoimmunity in patients after clonal repopulation with antitumor lymphocytes. Science 2002, 298:850-854.

81. Rosenberg SA, Yang JC, Sherry RM, Kammula US, Hughes MS, Phan GQ, Citrin DE, Restifo NP, Robbins PF, Wunderlich JR, Morton KE, Laurencot CM Steinberg SM, White DE, Dudley ME: Durable complete responses in heavily pretreated patients with metastatic melanoma using T-cell transfer immunotherapy. Clin Canc Res 2011, 17:4550-4557.

82. Ertl HC, Zaia J, Rosenberg SA, June CH, Dotti G, Kahn J, Cooper LJ, Corrigan-Curay J, Strome SE: Considerations for the clinical application of chimeric antigen receptor T cells: observations from a recombinant DNA Advisory Committee Symposium held June 15, 2010. Canc Res 2011, 71:3175-3181.

83. Chapuis AG, Thompson JA, Margolin KA, Rodmyre R, Lai IP, Dowdy K, Farrar EA, Bhatia S, Sabath DE, Cao J, Li Y, Yee C: Transferred melanomaspecific CD8+ T cells persist, mediate tumor regression, and acquire central memory phenotype. Proc Natl Acad Sci USA 2012, 109:4592-4597.

84. Kalos M, Levine BL, Porter DL, Katz S, Grupp SA, Bagg A, June CH: T cells with chimeric antigen receptors have potent antitumor effects and can establish memory in patients with advanced leukemia. Sci Trans/ Med 2011, 3:95ra73.

doi:10.1186/2051-1426-1-12

Cite this article as: Harris and Drake: Primer on tumor immunology and cancer immunotherapy. Journal for ImmunoTherapy of Cancer 2013 1:12.

\section{Submit your next manuscript to BioMed Central and take full advantage of:}

- Convenient online submission

- Thorough peer review

- No space constraints or color figure charges

- Immediate publication on acceptance

- Inclusion in PubMed, CAS, Scopus and Google Scholar

- Research which is freely available for redistribution

Submit your manuscript at www.biomedcentral.com/submit
C Biomed Central 